of the hind wing is somewhat reduced in size, being about two-thirds the size of vein 4 , and arises slightly below the middle of the discocellulars. If placed in the Acronyctinæ, it falls by Hampson's tables into Bagisara Walker; if in the Erastriinæ, into Eustrotia Hübner. Where the differential character is so nicely balanced and the larva unknown, characters of facies may properly be considered. The colors and style of maculation suggest Palindia merta Schaus (= Homopyralis albifasciata Schaus). This species is now placed in Lithacodia, which is the genus next to Eustrotia in the Erastriinæ. The indications are, therefore, that the form under discussion belongs to the Erastrïnæ. It may be separated from Erastria by the position of vein 5 of the hind wing, which arises considerably nearer the middle of the cell than in that genus. I therefore propose the new generic term Brabantia, in honor of the describer. Brabantia rhizoleuca was described from females, as the description shows, although not so stated. I possess a male, which shows some peculiar differences. The hind wings are white with a brown border, widest at the apex, not entirely brown as in the female. The palpi have the third joint short and thick, not as long as wide, whereas that joint in the female is markedly long, nearly half as long as the second joint, which reaches the vertex of the head, thus presenting a marked structural difference in the sexes.

\title{
FOUR NEW SPECIES OF NORTH AMERICAN CHLOROPIDÆ
}

(Diptera)

By J. R. MALLOCH

Tricimba spinigera, new species.

Female : Frons opaque, black-brown, anteriorly yellowish, breadth at vertex slightly less than at anterior margin, at narrowest part rather more than one-third the width of head; ocellar region and frontal triangle shining black, the latter very short, not exceeding one-half the length from vertex to anterior margin, a central, pale line carried from anterior angle of triangle to anterior margin of frons; surface hairs short, sparse, pale; antennæ small, half hidden below the slightly projecting frons, yellow, the third joint sometimes browned above; arista brown, pale at base, the basal two joints hardly swollen, bare; face yellow, concave in profile, 
the anterior margin of cheeks slightly produced; cheeks of moderate and regular width, yellow, the upper portion white pollinose, the lower margin narrowly browned; palpi and proboscis yellow. Mesonotum black, shining, slightly gray dusted; the center line of punctures single, narrow; the two outer lines broad and deep, all three lines opaque; each side of the furrows, or lines of punctures, has a series of short, pale hairs arranged closely on the margins, between the central and outer furrows there is a single line, on each side, of similar hairs, and beyond the outer furrows the hairs are more irregularly arranged; pleuræ black-brown, gray dusted; scutellum subglobose, black, the surface slightly warty in appearance and with scattered, pale hairs as on mesonotum, margin with four short tubercles, on the apices of each of which is a pale, short, thorn-like bristle. Abdomen short and broad, shining black, or black-brown, venter yellowish; surface hairs pale. Legs yellow, generally with all femora darkened on middle, and the hind tibia with a brown band near base and another near apex; the other tibiæ are sometimes darkened on the basal half; tarsi pale except the apical joint, which is brown. Wings clear, veins black-brown; third and fourth veins upward bent, but slightly divergent; outer cross vein very acutely placed, almost parallel with the hind margin of wing; last section of fifth vein distinctly longer than penultimate section of fourth. Halteres yellow, knobs whitish.

Length, $1 \mathrm{~mm}$.

Male : Similar to female in all respects but as a rule more distinctly varied in color of legs; the hypopygium is of normal size, shining black.

Type: Cat. No. 15672, U. S. Nat. Mus.

Locality : Rock Creek, District of Columbia (R. C. Shannon). Taken from old birds' nests February 10, 1913.

Paratypes: Same locality as type, 38 specimens representing both sexes; 1 specimen District of Columbia (collection Coquillett); and one Plummers Island, April 19, 1903 (H. S. Barber).

This species probably has no connection with birds' nests other than in its selection of them as its hibernation quarters, as I have seen several specimens reared from Morchella esculenta and M. conica by F. J. Veihmeyer, Takoma Park, District of Columbia, April-May, 1912.

Botanobia (= Oscinis) confusa, new species.

Male : Yellow, shining. Antennæ black, the basal two joints paler; frontal triangle more or less brown or black. Mesonotum highly pol- 
ished, the disk reddish-yellow, or with indications of three brownish yellow stripes. Abdomen brown or brown-black. Legs with only the tarsi slightly browned. Wings slightly grayish; veins brown.

Frontal triangle slightly rounded on posterior lateral margins, where it falls short of reaching the margins of frontal stripe, and distinctly short of reaching anterior margin of frons; surface hairs on frons black, those on lateral margins setulose; arista with rather distinct pubescence ; proboscis and palpi normal; cheeks narrow, about one-sixth the height of eye, lower half with numerous, distinct hairs; eyes shortly but distinctly haired. Hairs on mesonotum pale, rather long and numerous, bristles black; pleuræ unmarked; scutellum paler than mesonotum, convex, outline regularly rounded, disk bare, four marginal bristles present, the apical two very long and widely separated, the basal two very short, and close to the apical pair, sometimes there is also present a small hair on each side anterior to the basal bristle. Abdomen slender, longer than thorax, highly shining, the surface hairs yellowish. Legs thickly covered with pale hairs. Wings narrow; costa and posterior margin with unusually long marginal hairs; second costal division about one-third longer than third; third and fourth veins subparallel; last section of fifth vein distinctly longer than penultimate section of fourth, and not reaching wing margin; outer cross vein with its upper extremity distinctly nearer to wing tip than its lower. Halteres yellow, knob pale yellow.

Length, $1.5 \mathrm{~mm}$.

Type: Cat. No. 15673, U. S. Nat. Mus.

Locality: Bayamon, Porto Rico, January, 1899 (Busck).

Paratypes: Utuado and Aguadilla, Porto Rico, and Vieques Island, January and February, 1899 (Busck). Both sexes, 7 specimens. Female similar to the male in color, etc.

This species has been recorded by Coquillett (Proc. U. S. Nat. Mus., vol. 22, 1900) as Oscinis virgata Coq. While close to that species in some respects it differs in being smaller, in having the mesonotum unstriped, or indistinctly striped, in having the pleuræ unspotted, and in the less thickened arista, etc. Confusa is more nearly allied to mitis Williston (Oscinis) than to Coquillett's species, but mitis has the antennæ entirely yellow, and differs in several other respects from confusa. Becker's species, rubicunda, comes close to confusa but he gives the third and fourth veins as parallel in his description, while there are other minor differences also present. 


\section{Botanobia (=Oscinis) catalpæ, new species.}

Female : Glossy black; anterior margin of frons, antennæ, palpi, fore coxæ, and all tarsi yellow, more or less tinged with brown. Face brownish, and, with cheeks on upper half, silvery white pollinose. Halteres yellow, with white knob. Wings vitreous, veins yellow.

Frons highly glossy, with numerous slight longitudinal striæ; frontal triangle rather narrow and ill-defined, occupying slightly more than onehalf the width of frons at vertex, reaching almost to anterior margin; width of frons about equal to that of either eye at anterior margin, distinctly wider at vertex; surface hairs absent except for some along the margins of the frontal triangle; eyes bare, elongate, the length being about 1 1-3 that of the height; face concave in profile, keel slight; cheek about one-third as high as eye, and of almost regular height on its entire length, the lower half glossy brown from near anterior margin, and meeting the concolorous occiput, rather wider than at its anterior portion; marginal hairs on cheek weak, pale; palpi large, rather spatulate, slightly projecting, almost bare; antennæ of average size, third joint disk-like, arista hair-like, bare, basal joints slightly thickened, length of arista barely more than that of breadth of frons at anterior margin. Mesonotum thickly covered with pale hairs, each of which is set in a shallow puncture; scutellum flattened on surface, in outline rounded, disk with numerous hairs, except at base, and with distinct punctures, margin with two closely approximated long bristles and two short ones, at the base of each of which there are very slight indications of a swelling on the margin. Legs rather stout, surfaces covered with short, pale hairs. Wing with second costal division twice as long as third; third and fourth veins slightly divergent, third turned up at apex, and ending rather farther from apex of wing than usual; outer cross vein at an acute angle and slightly bent, the upper extremity distinctly nearer to apex of wing than the lower.

Length, $1.5 \mathrm{~mm}$.

Type: Cat. No. 15743, U. S. Nat. Mus.

Locality of type: Germantown, Pennsylvania.

Locality of other specimens in collection: North Bend, Ohio.

Reared from larvæ found in pods and seeds of Catalpa.

This species was identified as Oscinis longipes Loew, ${ }^{1}$ which is a slender species with black palpi. The nearest described species to catal-

${ }^{1}$ Bull. 10, n. ser., U. S. Dept. Agr., Div. Ent., p. 74, 1898. 
pa is magnipalpis Becker, which has the frons almost twice as wide as either eye, dark reddish brown in color, and red anteriorly; surface of frons with short black hairs; frontal triangle reaching only to middle of frons; legs, including fore coxæ, reddish yellow, femora and tibiæ broadly brown.

\section{Eugaurax insularis, new species.}

Female: Yellow, subshining. Frons opaque yellow, width barely more than equal to that of either eye; triangle short, not half as long as frons, subshining, surface hairs, pale short, bristles as in E. floridensis Malloch; ocellar region black; face, cheeks, and antennæ yellow, third joint of antennæ slightly darkened above, arista slightly longer than width of frons, yellow at base, brown apically, not swollen, sparsely and shortly pubescent; cheeks about one-eighth the height of eye; eye about onethird higher than long, hairy; palpi and proboscis yellow. Mesonotum with 6 black vittæ, the middle pair narrowly separated, the submarginal pair posteriorly abbreviated, the pair above wing base short and spot-like; the bristling as in floridensis, but there are 5-6 notopleural bristles present; pleuræ immaculate; scutellum with two strong, black, apical bristles, and numerous weaker bristles irregularly arranged on lateral margins. Abdomen with all segments suffused with brown; surface covered with weak, pale hairs. Legs entirely yellow; claws black, rather long. Wings clear; second costal division nearly three times as long as third; outer cross vein slightly oblique; veins almost colorless. Halteres yellow.

Length, $1.5 \mathrm{~mm}$.

Type: Cat. No. 15744, U. S. Nat. Mus.

Type locality: Fajardo, Porto Rico (Busck).

Paratype: Bayamon, Porto Rico (Busck).

The only other species of this genus was described in April, 1913, Ins. Insc. Mens., p. 46.

Date of publication, May 31, 1913. 


\section{$2 \mathrm{BHL}$ Biodiversity Heritage Library}

1913. "Four new species of North American Chloropidae." Insecutor inscitiae menstruus 1, 60-64. https://doi.org/10.5962/bhl.part.9561.

View This Item Online: $\underline{\text { https://www.biodiversitylibrary.org/item/36243 }}$

DOI: https://doi.org/10.5962/bhl.part.9561

Permalink: https://www.biodiversitylibrary.org/partpdf/9561

\section{Holding Institution}

Smithsonian Libraries

\section{Sponsored by}

Smithsonian

\section{Copyright \& Reuse}

Copyright Status: NOT_IN_COPYRIGHT

This document was created from content at the Biodiversity Heritage Library, the world's largest open access digital library for biodiversity literature and archives. Visit BHL at https://www.biodiversitylibrary.org. 